\title{
Design and construction of the barrier system for the Halton Landfill
}

\author{
R. Kerry Rowe, Chris J. Caers, Glenn Reynolds, and Cliff Chan
}

\begin{abstract}
Considerations related to the design of the Halton Landfill as a "hydraulic trap" are summarized together with the research that was conducted to support the design concept. The interrelationship between hydrogeology and the engineered design is examined. Laboratory experiments demonstrated that there can be diffusion away from a source, even with significant inward velocity. Existing theory was found to provide a good prediction of the observed concentration profile in these experiments. It is also shown that a pressurized air pocket below the clay effectively acts as a zero-flux boundary and hence, with respect to migration of chloride, could be conservatively neglected in the impact assessment. The results of the impact calculations predict only a small increase in chloride concentration in the receptor aquifer while there is negligible predicted impact due to organic contaminants. The landfill was designed and constructed with a granular "sub-liner contingency layer" (SLCL) beneath the compacted liner. The operation of this layer is discussed. Finally, the construction of the compacted clayey liner with a hydraulic conductivity of $1 \times$ $10^{-8} \mathrm{~cm} / \mathrm{s}$ is documented.
\end{abstract}

Key words: landfill, hydraulic containment, liner, field case, construction.

Résumé : On présente le résumé de considérations associées à la constructiion du site d'enfouissement de Halton conçu comme une «trappe hydraulique » de même que la recherche qui a été réalisée pour appuyer cette idée de conception. L'interrelation entre l'hydrogéologie et la conception de l'ouvrage est examinée. Des expériences en laboratoire ont montré qu'il peut y avoir de la diffusion s'éloignant de la source même avec une vélocité appréciable en direction de la source. On a trouvé que les théories existantes fournissent une bonne prédiction du profil de concentration observé dans ces expériences. On montre également qu'une poche d'air sous pression au-dessous de l'argile agit efficacement comme une barrière d'écoulement nul qui, en ce qui concerne la migration de chlorure, pourrait ainsi être négligé de façon sécuritaire dans l'évaluation environnementale. Les résultats des calculs d'impact prédisent seulement une faible augmentation de la concentration de chlorure dans l'aquifère récepteur et un impact négligeable des contaminants organiques. Le site d'enfouissement a été conçu et construit avec une couche granulaire de sécurité placée sous la membrane d'étanchéité (SLCL) d'argile compactée. On discute de l'opération de cette couche. Finalement, on présente des informations concernant la construction de la membrane d'étanchéité d'argile compactée ayant une conductivité hydraulique de $1 \times 10^{-8} \mathrm{~cm} / \mathrm{s}$.

Mots clés : remblai d'enfouissement, confinement hydraulique, membrane d'étanchéité, cas de terrain, construction.

[Traduit par la Rédaction]

\section{Introduction}

The search for a suitable landfill site for the Regional Municipality of Halton extended over more than a decade, culminating in a Hearing before a Joint Board under the Ontario Consolidated Hearings Act. The Hearing began on 5 May 1987 and concluded on 8 November 1988 after 194 days of evidence and almost fifty thousand pages of transcript. On 24 February 1989 the Joint Board granted ap-

Received February 19, 1998. Accepted November 15, 1999.

R.K. Rowe. Department of Civil and Environmental Engineering, University of Western Ontario, London, ON N6A 5B9, Canada.

C.J. Caers. Earth Tech, 45 Goderich Road, Suite 201, Hamilton, ON L8E 4W8, Canada.

G. Reynolds. Gartner Lee Ltd., Suite 102, 140 Renfrew Drive, Markham, ON L3R 6B3, Canada.

C. Chan. Public Works Department, Regional Municipality

of Halton, P.O. Box 7000, Oakville, ON L6M 3L1, Canada. proval to develop a sanitary landfill to contain $7.96 \times 10^{6} \mathrm{~m}^{3}$ of waste. The approved Halton Waste Management Site is located on the west side of Regional Road 25, south of Britannia Road and north of Lower Baseline Road in the Town of Milton, Ontario, Canada. The site covers approximately 126 ha, with an approved landfill area of 53 ha.

Following approval by the Joint Board, a detailed hydrogeologic investigation was performed and a design was developed which complied with the conditions attached to the board decision and the subsequent Ministry of the Environment Provisional Certificate of Approval. The design involves the progressive development of the landfill, as a number of cells, over at least a 20 year period. Figure 1 shows the proposed footprint of the landfill, the cell layout, and the pipe layout for the primary leachate collection system. All directions referred to in this paper are referenced to "study north" shown in Fig. 1. As designed, the barrier system cross section (see Fig. 2) involves a primary leachate collection system consisting of $200 \mathrm{~mm}$ diameter perforated pipes located in a $0.3-0.6 \mathrm{~m}$ thick stone layer over a $1.2-1.5 \mathrm{~m}$ thick 
Fig. 1. Landfill layout showing leachate collection pipes in the primary leachate collection system.

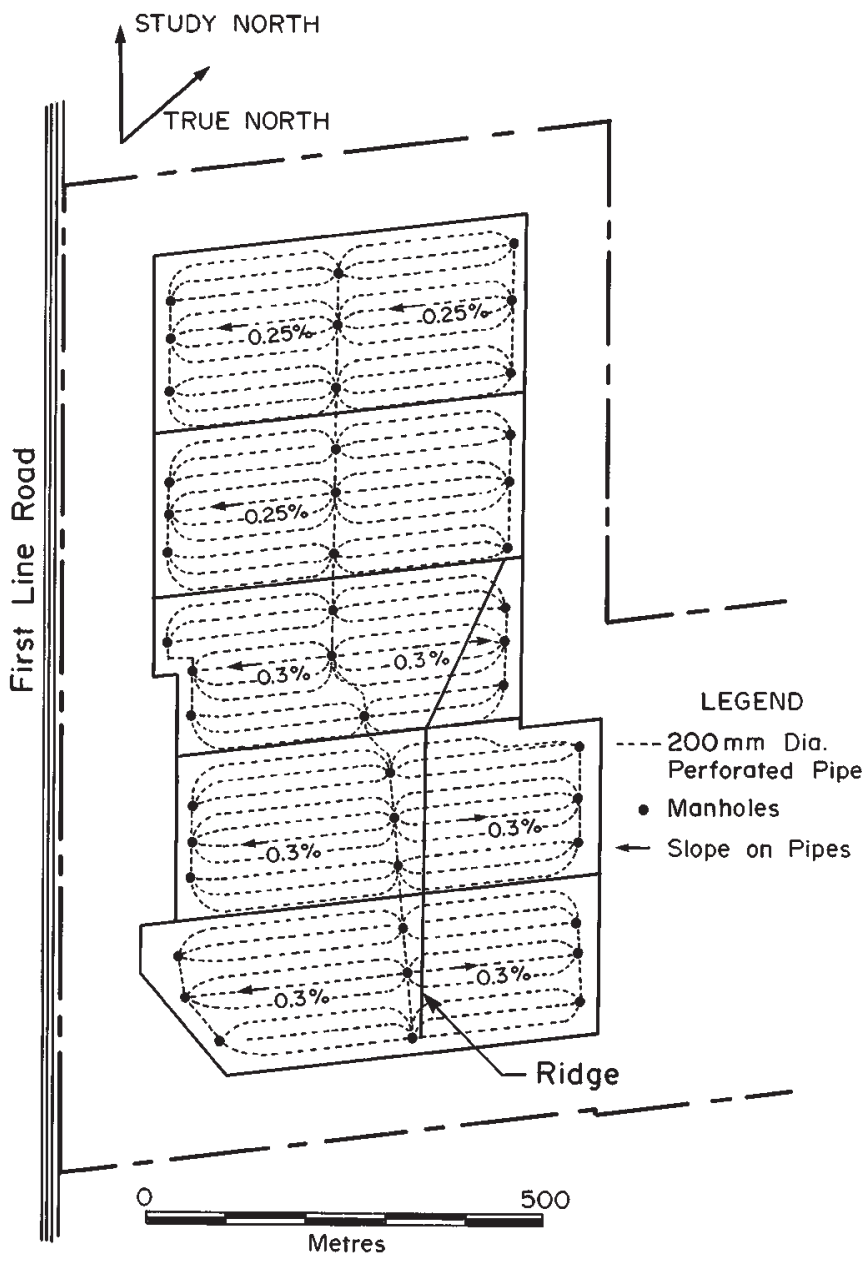

recompacted clayey silt till liner, which in turn overlies a $0.3 \mathrm{~m}$ thick stone layer and pipes that form the "sub-liner contingency layer" (SLCL). Figure 3 shows the top of the sub-liner contingency layer (i.e., bottom of the compacted clay liner) and the piping system in the SLCL. Because of the contouring of the landfill base to provide a $3 \%$ slope to the collection pipes (see Fig. 2), the top of the clay liner varies between 1.2 and $1.5 \mathrm{~m}$ above the contours shown in Fig. 3. The bottom of the excavation is $0.3 \mathrm{~m}$ below the contours shown. All stone layers (see Fig. 2) were specified to be gravel with a nominal size of $39 \mathrm{~mm}$.

A fundamental feature of the Halton Waste Management Facility and its approval by the Joint Board is that the landfill (hereafter called the Halton Landfill) was proposed as a "hydraulic trap" wherein the landfill is designed and operated such that water flows into the landfill from the underlying aquifer and hence eliminates outward advective transport. It also reduces outward diffusive movement of contaminants relative to what would occur if there were no hydraulic trap.

A detailed study of the feasibility of constructing this barrier system was conducted prior to landfill construction (see Rowe et al. 1993). Construction of the landfill commenced in the summer of 1991. The barrier system (liner and collection systems) of the southwestern portion of cell 1 (4 ha) was constructed during the summer and autumn of 1992, and the first load of waste was accepted in September 1992. Construction of the northwestern ( 2 ha) and eastern (4 ha) portions of cell 1 was completed in the autumn of 1993 and 1995, respectively. A portion of the barrier system for cell 2 (the western 5.5 ha, referred to herein as cell 2 (west)) was constructed during the summer and autumn of 1998.

The approval of the Halton Landfill as a hydraulic trap was a benchmark decision that was followed by the proposal and approval of a number of other landfills (e.g., Grimsby, North Simcoe, and Essex-Windsor landfills) based on the

Fig. 2. Cross section through the barrier system.

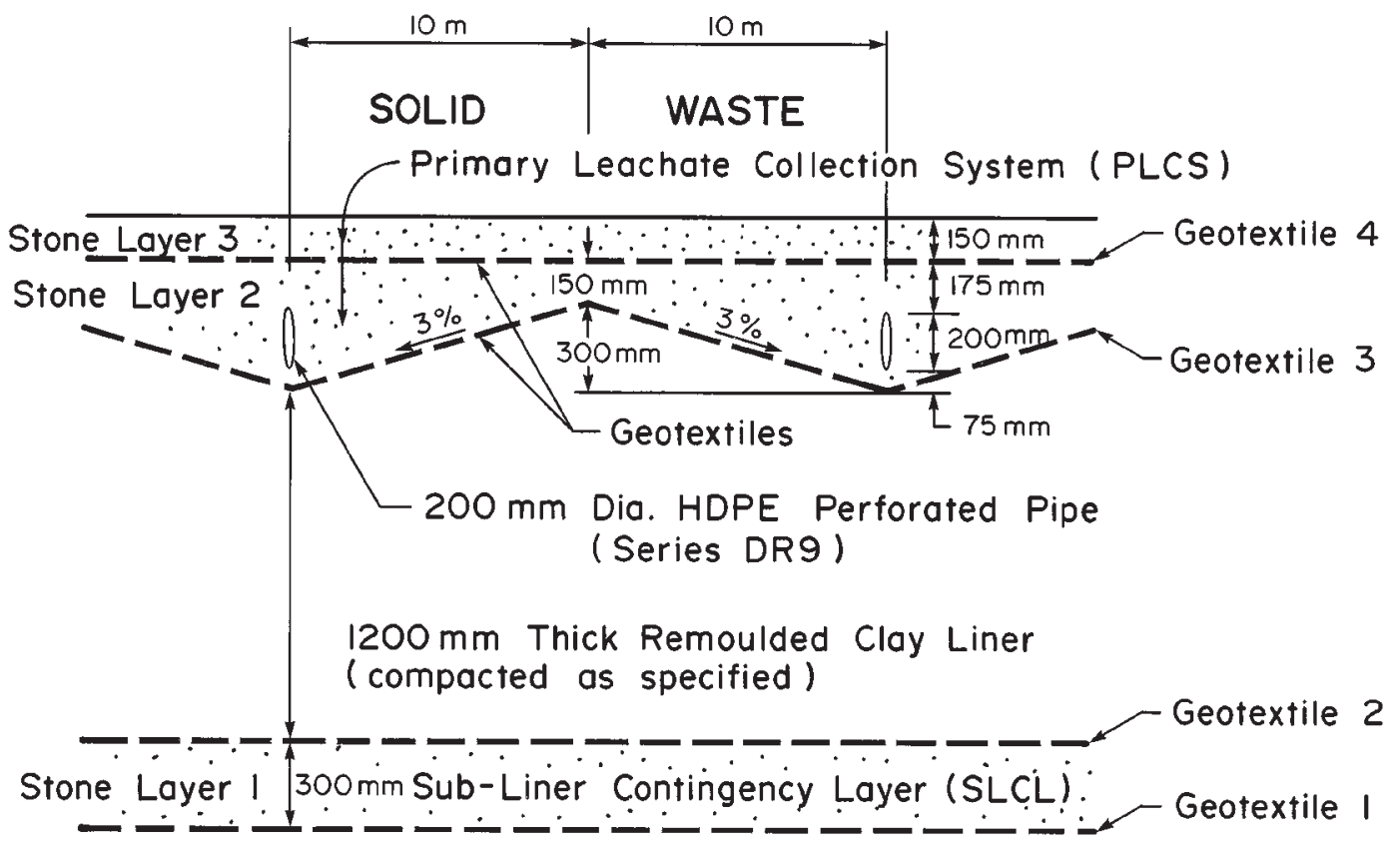

(as needed) 
Table 1. Hydrogeologic characteristics of key units.

\begin{tabular}{|c|c|c|c|c|c|c|}
\hline \multirow[b]{2}{*}{ Unit } & \multicolumn{2}{|c|}{ Thickness (m) } & \multirow{2}{*}{$\begin{array}{l}\text { Clay } \\
\text { content } \\
(\%)\end{array}$} & \multicolumn{3}{|c|}{$\underline{\text { Hydraulic conductivity }(\mathrm{cm} / \mathrm{s})}$} \\
\hline & Range & Average & & $\begin{array}{l}\text { Pumping test } \\
\text { (vertical) }\end{array}$ & $\begin{array}{l}\text { Triaxial test } \\
\text { (vertical) }\end{array}$ & Horizontal \\
\hline Lower till above UGU & $1-7$ & 4 & $13-20$ & $9 \times 10^{-9}$ to $4 \times 10^{-8}$ & $4 \times 10^{-9}$ to $4 \times 10^{-8}$ & $2 \times 10^{-7}$ to $7 \times 10^{-5}$ \\
\hline Upper granular unit (UGU) & $0.1-2$ & 0.6 & - & - & - & $6 \times 10^{-4}$ to $4 \times 10^{-3}$ \\
\hline
\end{tabular}

same concept. Landfills that have been proposed as hydraulic trap designs have also been approved in the United States (see Burke and Haubert 1991). Thus, the objective of this paper is to discuss some of the key considerations and research related to the final design of the Halton Landfill. Specifically, the paper addresses the issues itemized below:

(1) The design of a hydraulic trap assumes that the potentiometric surface of the aquifer will be above the landfill base contours. This paper describes the hydrogeologic conditions and documents the natural changes in water levels that occurred between the initial site investigation and the final design. It also documents the calculation of the changes in water level that could occur due to construction of the landfill and an assessment of potential impact due to a change in groundwater flow conditions.

(2) At the time of approval of the hydraulic trap concept, there was no experimental evidence that existing techniques could predict outward diffusion against an inward advective flow. This paper summarizes experimental data supporting this concept and its modelling. Consideration is also given to what happens if there is a small air pocket caught below the compacted clay liner.

(3) Recognizing the potential uncertainties, the landfill was designed and constructed with a sub-liner contingency layer (SLCL). This paper discusses the operation and monitoring of this layer and the potential for its use to control impact on the aquifer in the event that unexpected contaminant concentrations were observed in the SLCL.

(4) The potential impact of the landfill on the underlying receptor aquifer is discussed for a number of scenarios, including operating conditions, failure of the primary leachate collection system, termination of the monitoring-operation of the sub-liner contingency layer, and an unexpected drop in water levels in the receptor aquifer.

(5) Since there was evidence of fracturing in the natural aquitard, it was necessary to construct a low hydraulic conductivity liner from the local soil (see Fig. 2). The compaction specifications and data from the construction of 10 ha of liner for cell 1 and 5.5 ha of liner for cell 2 are discussed.

\section{Hydrogeologic conditions}

\section{Hydrostratigraphy}

The detailed (1990-1991) hydrogeologic investigation included two deep test pits, numerous boreholes (including two boreholes angled at $45^{\circ}$ ), water-level monitoring, several pumping tests, geochemical and mineralogical analyses, and diffusion tests.

The hydrostratigraphy of the site, which is located on a moderately to poorly drained glacial till plain, is shown schematically in Fig. 4 and summarized in Table 1. The soil,
Fig. 3. Landfill layout showing contours (in metres asl) at the top of the SLCL (bottom of compacted clay liner), piping in the SLCL, and manholes connected to the SLCL. The bottom of the SLCL is $0.3 \mathrm{~m}$ below the values shown.

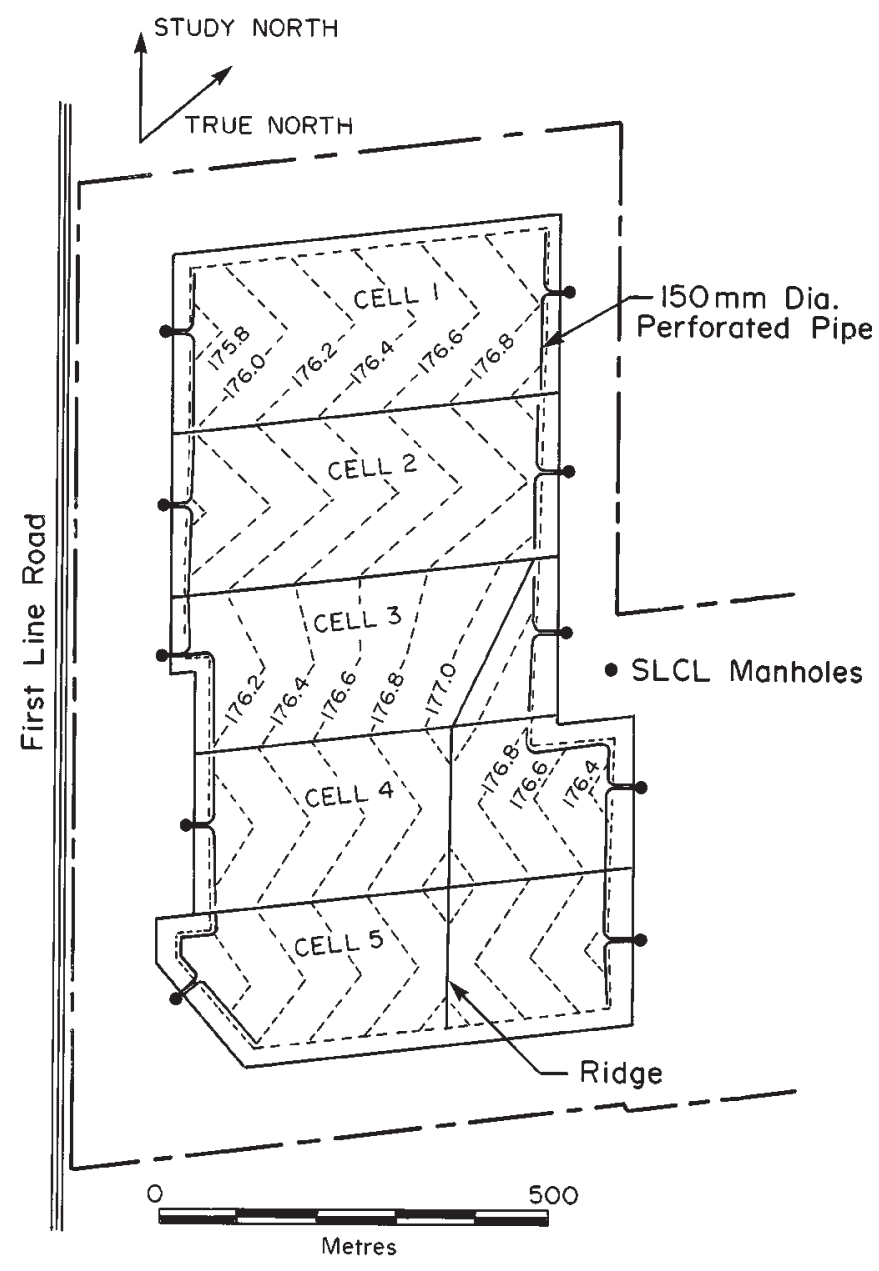

known as Halton Till, ranges from clayey silt till (referred to as upper till, see Fig. 4) for the upper 6-10 m (with the upper $3.5 \mathrm{~m}$ being weathered) to a sandy silt till (lower till) for the underlying 9-23 m (average $18 \mathrm{~m}$ ). The upper till was observed to be fractured through its entire thickness at many locations both in the test pits and in the excavation for cells 1 and 2. The vertical fractures had a $0.5 \mathrm{~m}$ spacing at the bottom of the upper till but did not appear to penetrate through a thin silt bed which separated the upper and lower tills. The till includes water-bearing layers of glaciolacustrine and glaciofluvial sand, silt, and gravel which are still used by the local residents as a source of water for both domestic and agricultural use. A number of domestic wells are located 
Fig. 4. Inferred stratigraphy, calibrated hydraulic conductivities $(k)$, and boundary conditions used in flow modelling.

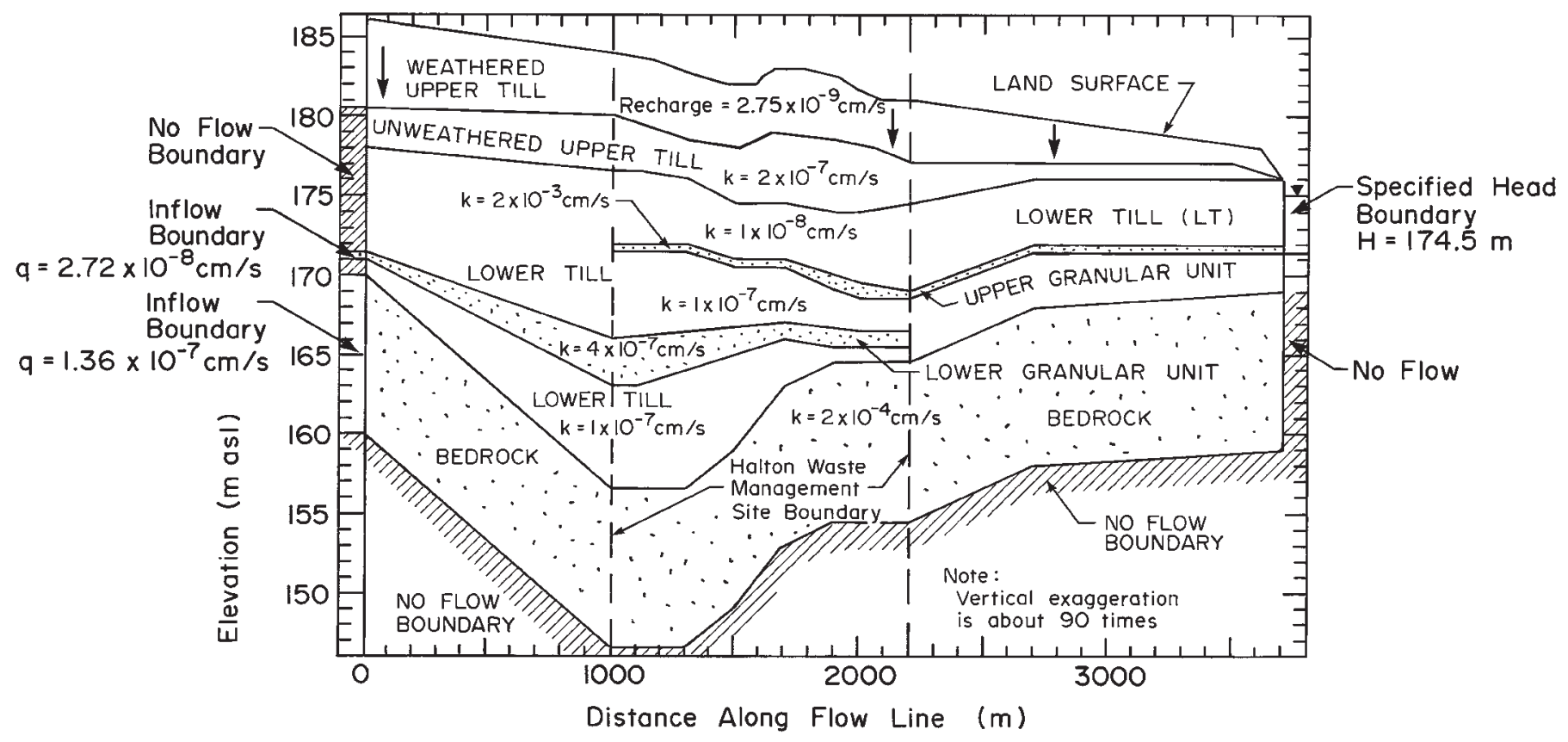

within $60 \mathrm{~m}$ of the west site boundary (i.e., west of "First Line" Road, see Fig. 5). Of greatest significance with respect to landfill design is the upper silty sand to fine gravel aquifer that is referred to as the upper granular unit (UGU) (see Fig. 4). The Halton Till is underlain by reddish fractured Queenston shale.

\section{Groundwater levels}

Prior to landfill construction, groundwater flow was generally downward across the unweathered upper till and underlying lower till. In several monitoring nests, most of the head loss is across the lower till, with less across the unweathered upper till. This is consistent with the evidence of fracturing and the correspondingly higher hydraulic bulk conductivity (as inferred from pumping tests on the UGU) of the unweathered upper till than the lower till (see Table 1).

Flow in the UGU (see Fig. 5) is essentially lateral, with flow from the north (cell 1) towards the southwest (cells 3 and 4) and then to the west. There is also a component of flow beneath cells 4 and 5 towards the east as shown in Fig. 5.

The evidence regarding water levels presented to the Joint Board in 1987 was based on water levels measured in 1985 and 1986. In 1990-1992 when the detailed hydrogeologic investigation was performed, the water levels were lower than those in 1986 by between 0.6 and $2.8 \mathrm{~m}$ (Gartner Lee Ltd. 1991). This resulted in significant lowering of the landfill base contours (relative to that proposed in 1986) (Hydrology Consultants Ltd. 1986). It appears that the late 1980s was a period of unusually low precipitation (compared with the 1950-1980 average).

\section{Groundwater chemistry}

The natural groundwater quality (prior to landfilling) is generally poor, with relatively high concentrations of
Fig. 5. Inferred potentiometric surface and flow directions in the upper granular unit (UGU) based on data for 16 January 1991. Contours in metres asl.

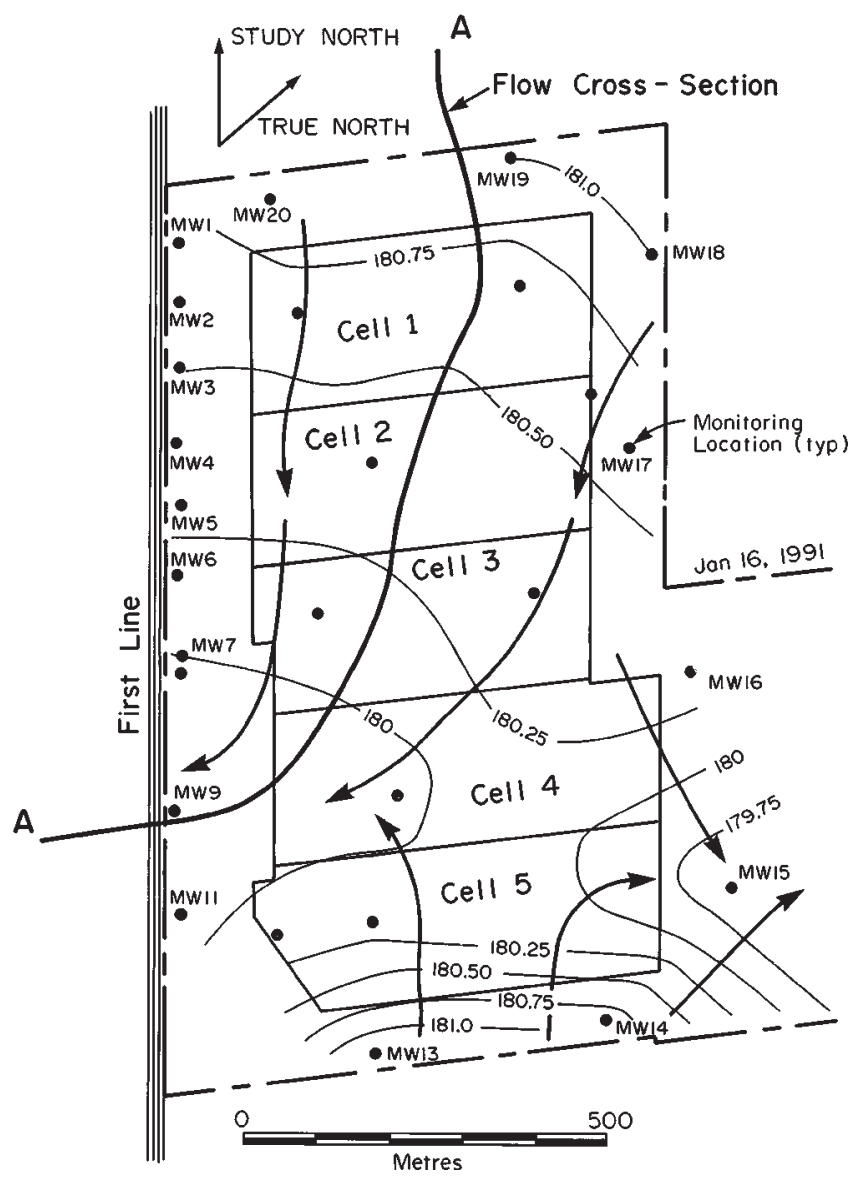


Table 2. Average chloride concentration based on 1990-1992 monitoring data.

\begin{tabular}{|c|c|c|c|c|c|c|}
\hline \multirow[b]{2}{*}{ Monitor } & \multicolumn{2}{|c|}{$\underline{\text { Bedrock }}$} & \multicolumn{2}{|l|}{$\underline{\mathrm{LGU}}$} & \multicolumn{2}{|l|}{ UGU } \\
\hline & Mean & sd & Mean & sd & Mean & $\mathrm{sd}$ \\
\hline MW1 & 1091 & 120.6 & 396 & 55.7 & 407 & 53.4 \\
\hline MW3 & 787 & 44.0 & 372 & 14.7 & 217 & 42.1 \\
\hline MW4 & 901 & 97.6 & 350 & 17.2 & 291 & 37.1 \\
\hline MW5 & 692 & 27.7 & 405 & 28.8 & 350 & 18.9 \\
\hline MW9 & 1558 & 275.4 & $*$ & $*$ & 483 & 24.5 \\
\hline MW11 & 404 & 45.9 & 345 & 9.7 & 347 & 18.2 \\
\hline MW13 & 107 & 13.7 & $*$ & $*$ & 17 & 0.5 \\
\hline MW14 & 774 & 158.1 & 106 & 15.7 & 45 & 2.8 \\
\hline MW15 & 3745 & 126.1 & 441 & 29.8 & 188 & 7.5 \\
\hline MW20 & 2388 & 201 & 556 & 25.4 & 268 & 23.8 \\
\hline Average of all wells & 1234 & & 410 & & 264 & \\
\hline
\end{tabular}

Note: LGU, lower granular unit; UGU, upper granular unit.

*Interpreted as not present at this location.

sulphate, chloride, calcium, magnesium, and sodium. Of particular note are the chloride values, since chloride is commonly used as a tracer for assessing contaminant migration from landfills. Table 2 summarizes the mean $( \pm s d)$ chloride concentrations at 17 locations for the bedrock, lower granular unit (LGU), and UGU.

The bedrock, which consists of fractured shale, has chloride concentrations that are generally elevated above the Ontario drinking water objective (ODWO) of $250 \mathrm{mg} / \mathrm{L}$. The concentrations are highly variable from one location to another, with an average concentration of all monitors being about $1200 \mathrm{mg} / \mathrm{L}$.

The LGU has lower concentrations of chloride than the bedrock but still typically exceeds the ODWO at all locations where the LGU is present except MW14 south of the site. The average concentration in all the monitors in the LGU is $410 \mathrm{mg} / \mathrm{L}$.

The UGU is the primary potential receptor for contaminants from the landfill. The groundwater quality in the UGU north of the site (monitors MW1, MW2, MW3, MW4, MW5, MW6, MW17, MW18, MW19, and MW20; see Fig. 5) is generally poor, with an average concentration of $286 \mathrm{mg} / \mathrm{L}$. The flow to the west (beneath First Line Road) near monitors MW9 and MW11 has an average of $415 \mathrm{mg} / \mathrm{L}$, which exceeds the ODWO. Since this is a source of water for local residents, in terms of the MOE Reasonable Use Guideline and Procedure B-7 (MOE 1994) no chloride may be added to the groundwater at the site boundary along First Line Road. The standard deviations of the chloride concentrations at MW9 and MW11 are 24 and $18 \mathrm{mg} / \mathrm{L}$, respectively.

The existing groundwater quality is such that consideration needs to be given to the potential impact that simply constructing the landfill may have on groundwater quality, even if there were no contaminant migration from the landfill. This will be discussed later.

\section{Selection of base contours and assessment of potential impact due to landfill construction}

Previous research relating to landfill impacts has focussed on the impact of the landfill due to the migration of leachate. However, in the development of a hydraulic trap design, which is intended to minimize contaminant migration, there are two other potential impacts that require consideration.

The first is the change in groundwater levels (sometimes called the shadow effect) as a result of (i) the cutoff of natural recharge at the site due to landfill construction, and (ii) the removal of water from the aquifer to maintain the hydraulic trap due to the induced inward flow to the landfill. This change in groundwater levels would tend to reduce the effectiveness of the hydraulic trap.

The second potential impact is a change in groundwater chemistry due to the change in groundwater flow conditions induced by the creation of the hydraulic trap. These two issues will be discussed in the following sections.

\section{Selection of base contours}

The base contours were selected to $(i)$ ensure at least $0.25 \%$ slope on the leachate collection pipes and more where practical, (ii) ensure that the lowest measured potentiometric surface in the UGU was at least $0.4 \mathrm{~m}$ above the design leachate mound (this was required to satisfy the Conditions of Approval), (iii) minimize the excavation into the lower till.

The inferred elevation of the top of the UGU is highest at the northeast of the footprint and drops to the southwest beneath cell 4. In general, the thickness of the lower till is greatest along the west of the landfill and least along the east. The thickness varies between 1 and $7 \mathrm{~m}$, with an average of about $4 \mathrm{~m}$. One of the objectives of the base design was to minimize the excavation of the lower till (the primary 
aquitard; see Table 1 and Fig. 4) and to keep the bottom of the landfill above the bottom of the upper till except where the lower till thickness exceeded $4 \mathrm{~m}$.

The constraints placed by the location of the bottom of the unweathered upper till, the thickness of the lower till, and the need to maintain a hydraulic trap with respect to the relatively flat potentiometric surface in the UGU (see Fig. 5) placed severe restrictions on the development of the base contours and, in particular, on the slope of the landfill base.

The base contours were initially developed based on the constraints discussed above and the lowest measured water levels for the period for which data were available (19851992). These base contours were then used in a flow analysis to be discussed later in the paper. This analysis resulted in significant changes to base contours of the landfill and, in particular, to a lowering of the northern cells (cells 1, 2, and 3) by up to $2 \mathrm{~m}$ relative to that required based on the lowest measured water level. The final contours for the base of the compacted liner are shown in Fig. 3; the base of the excavation was $0.3 \mathrm{~m}$ lower than the contours given in Fig. 3. For this design, the average thickness of the natural attenuation layer between the receptor aquifer (UGU) and the bottom of the engineered system (SLCL) was about $5.3 \mathrm{~m}$. The predicted head in the aquifer was $0.4 \mathrm{~m}$ (or greater) above the maximum design leachate level in the landfill.

The base contours are sufficiently close to the UGU that it is necessary to depressurize the UGU during excavation for and construction of the barrier system for each cell to ensure a sufficient factor of safety against basal heave (blow out).

\section{Flow modelling: pre-landfill construction}

A two-dimensional, cross-sectional flow model was used to calculate the steady-state potentiometric head, stream functions, and groundwater velocity fields along cross section A-A shown in Fig. 5. The stratigraphy along this profile (Fig. 4) was inferred based on interpretation of the site drilling results. This cross section was selected because $(i)$ it was essentially parallel to the inferred flow in the bedrock, the lower granular unit, and upper granular unit in January 1991; and (ii) it was considered to be representative of flow lines where there was the greatest potential for impact (both in terms of potentiometric head and contaminant impact) due to construction of the landfill.

The hydraulic conductivity values for each of the hydrogeological units were initially estimated based on field and laboratory data and applied uniformly to these units. These values were adjusted during model calibration but were kept within the range of test values. The final "calibrated" hydraulic conductivity values are given in Fig. 4.

The boundary conditions adopted for the flow modelling are also shown in Fig. 4. Horizontal flow in the weathered till was not modelled but, rather, the vertical recharge from the weathered upper till to the unweathered upper till was modelled as a recharge (flux) boundary with a calibrated recharge of $2.75 \times 10^{-9} \mathrm{~cm} / \mathrm{s}(0.9 \mathrm{~mm} / \mathrm{a})$.

A specified head boundary condition was imposed along the downgradient flow line to represent the unnamed creek. A no-flow boundary was imposed in the weathered bedrock unit to represent a presumed groundwater divide beneath the creek. The bedrock and UGU were both assumed to discharge to the creek at this location.
A flux boundary was imposed along parts of the vertical boundary at the upgradient edge of the cross section, with the flux being estimated based on the estimated recharge to the LGU and bedrock from a recharge area extending an additional $500 \mathrm{~m}$ upgradient of the model domain.

The bedrock was modelled as a $10 \mathrm{~m}$ thick transmissive layer with a calibrated transmissivity of $2 \times 10^{-5} \mathrm{~m}^{2} / \mathrm{s}$, underlain by a no-flow boundary.

The flow model was calibrated against observed water levels and gradients. The calibrated model was then used to predict the impact of landfill construction on the head and flow distribution as discussed in the following section.

Under existing conditions, the vertical gradients are essentially downward and the model gives downward flow of about $0.85 \mathrm{~mm} / \mathrm{a}$ to the UGU beneath the landfill and very little flow between the UGU and LGU beneath the site. The horizontal flow in the UGU at the location of the downgradient edge of the landfill was about $0.95 \mathrm{~m}^{3} /(\mathrm{a} \cdot \mathrm{m})$.

It should be noted that the accuracy of modelling the flow in a natural hydrogeologic system is limited by the variability of the available data and interpolation based on this data. Furthermore, the modelling of flow systems such as these does not provide a unique solution; other choices of hydraulic conductivity and flow boundary conditions could be used to obtain a similar distribution of potentiometric head. However, the conditions modelled were considered to be reasonable for the purposes of assessing the potential changes in groundwater flow conditions due to landfill construction.

\section{Flow modelling: landfill in operation}

To examine the potential interaction between the natural hydrogeologic system and the proposed landfill, flow modelling was conducted along section A-A. The conditions examined were the same as those in the calibrated model except in the area of the landfill. The SLCL (hydraulic conductivity $\left.k=1 \times 10^{-2} \mathrm{~cm} / \mathrm{s}\right)$ and liner $\left(k=3 \times 10^{-8} \mathrm{~cm} / \mathrm{s}\right)$ were explicitly modelled and the leachate head acting on the $1.2 \mathrm{~m}$ thick liner was assumed to be a constant value of $0.3 \mathrm{~m}$. As previously noted, the initial base contours (based on the 1991 potentiometric surface) were found to be too high and the base of the landfill at the north end of the site was lowered in obtaining the final contours.

Modelling of the final design indicated that the hydraulic trap would be maintained beneath the entire site, although the predicted head in the UGU decreased by about $2.2 \mathrm{~m}$ from $181.2 \mathrm{~m}$ above sea level (asl) to $179.0 \mathrm{~m}$ asl at the upgradient edge of the landfill and by about $1.5 \mathrm{~m}$ (from 179.75 to $178.25 \mathrm{~m} \mathrm{asl}$ ) at the downgradient edge of the landfill. The weighted average drop in head along section $\mathrm{A}-\mathrm{A}$ is $2.0 \mathrm{~m}$. This likely overestimates the drop in head that will actually occur due to landfill construction, since it assumes two-dimensional flow conditions and neglects any flow from the area around the sides of the landfill which could be expected to mitigate, to some extent, the head drop due to the shadow effect. Figure 6 shows the stream lines under predicted operating conditions.

\section{Potential for change in groundwater chemistry in the UGU due to changed groundwater flow conditions}

Prior to landfill construction, the vertical gradients at the site were generally downward and the UGU received most 
Fig. 6. Streamlines obtained from flow modelling of the final design. Note the concentration of streamlines in the UGU.

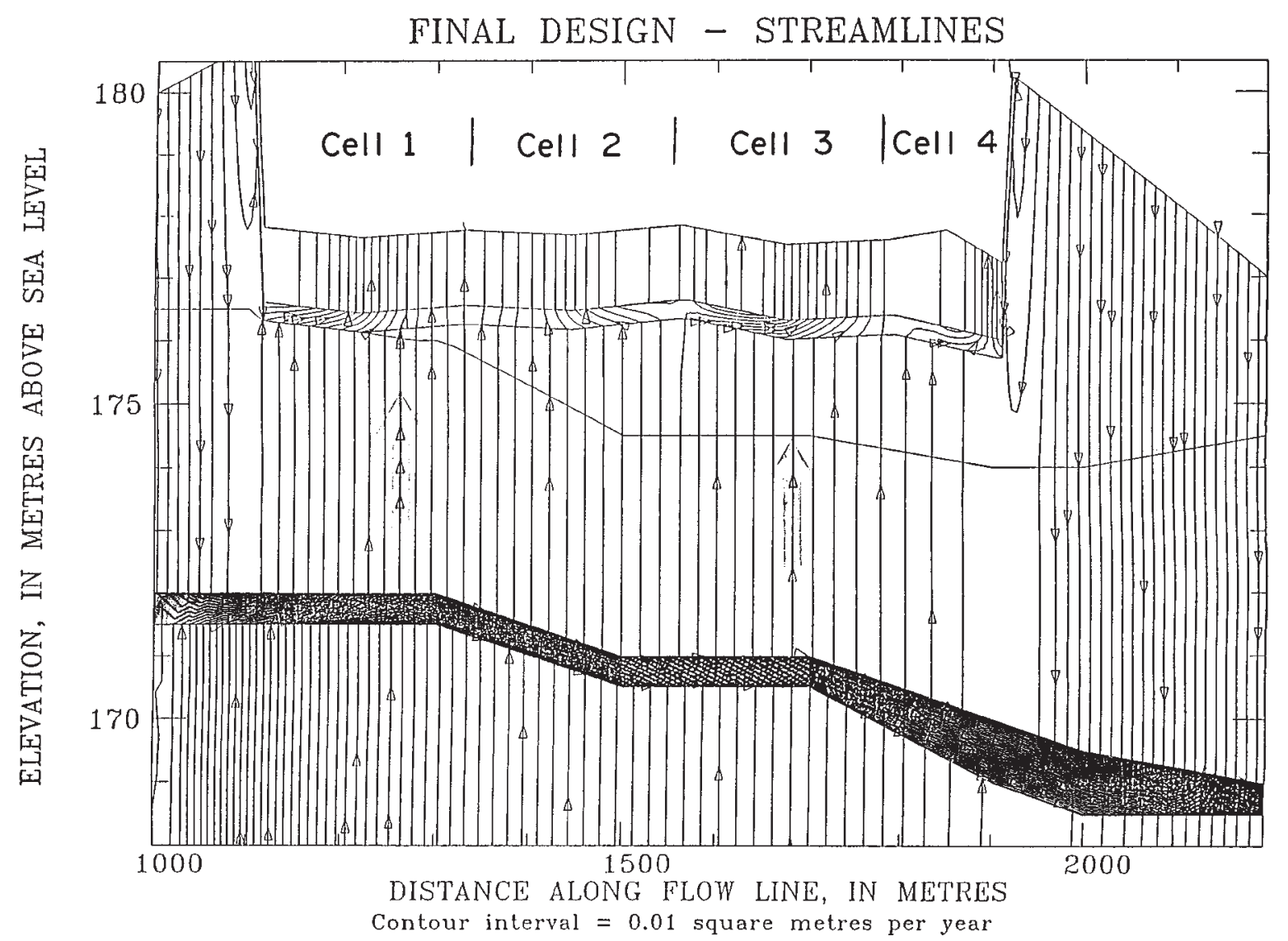

of its recharge from above. However, the construction of the landfill with a base well below the present potentiometric surface in the UGU and the operation of the landfill as a hydraulic trap will cutoff recharge to the UGU from beneath the landfill footprint and induce flow from the UGU toward the landfill (this is the hydraulic trap). Thus one would expect a change in the flow regime beneath the site. The flow modelling (see Fig. 6) predicted that after landfill construction the majority of flow $(90 \%)$ entering the UGU comes from the LGU-bedrock aquifer.

The average concentration of chloride in the bedrock is about $1230 \mathrm{mg} / \mathrm{L}$, whereas that in the LGU is about $410 \mathrm{mg} / \mathrm{L}$ and that in the UGU about $260 \mathrm{mg} / \mathrm{L}$. Thus, if sustained long enough, a change in flow conditions from current downward flow to upward flow from the bedrock and LGU to the UGU would be expected to result in increasing chloride concentration with time in the UGU, even if there is no contaminant migration from the landfill. However, the Darcy velocities (Darcy flux) are low and contaminant migration is still expected to be dominated by diffusion.

To assess the likely impact of advective diffusive transport of chloride from the bedrock toward the UGU and landfill, analyses were performed using the upward Darcy velocity deduced from Fig. 6 and a diffusion coefficient based on tests to be discussed in the following section. The calculated variation in chloride concentration with time in the UGU due to advection and diffusion from the bedrock is shown in Fig. 7, and it can be seen that there is very little effect on the UGU for the first 500 years. The landfill is expected to be closed and leachate collection terminated before this. After termination of the operation of the LCS and SLCL, downward flow conditions are expected to be reestablished. A degradation of groundwater quality in the UGU could still occur over a period of thousands of years due to diffusion from the bedrock; however, if this does occur, it is due to natural causes (not the landfill) and would have occurred irrespective of whether or not a landfill had been constructed.

\section{Sub-liner contingency layer}

The sub-liner contingency layer (SLCL) is a continuous, high hydraulic conductivity layer beneath each landfill cell (see Fig. 3). This layer was designed such that under normal operating conditions it would be saturated and passive (i.e., requiring no human intervention), with a small quantity of groundwater flowing from the UGU through the till, SLCL, and compacted clay liner. The SLCL in each cell is hydraulically isolated from that for adjacent cells so that each can be independently monitored and controlled. Although unsaturated secondary leachate systems are quite common, a saturated and pressurized sub-liner contingency layer is relatively uncommon in landfill design, and hence the following subsections provide details regarding the design and operation of this layer.

\section{Construction considerations}

Some important considerations in the design and construction specifications for the SLCL are itemized below. 
Fig. 7. Calculated chloride concentration variation with time in UGU due to upward advective-diffusive transport from the bedrock and LGU due to the hydraulic trap being maintained for the time period indicated.

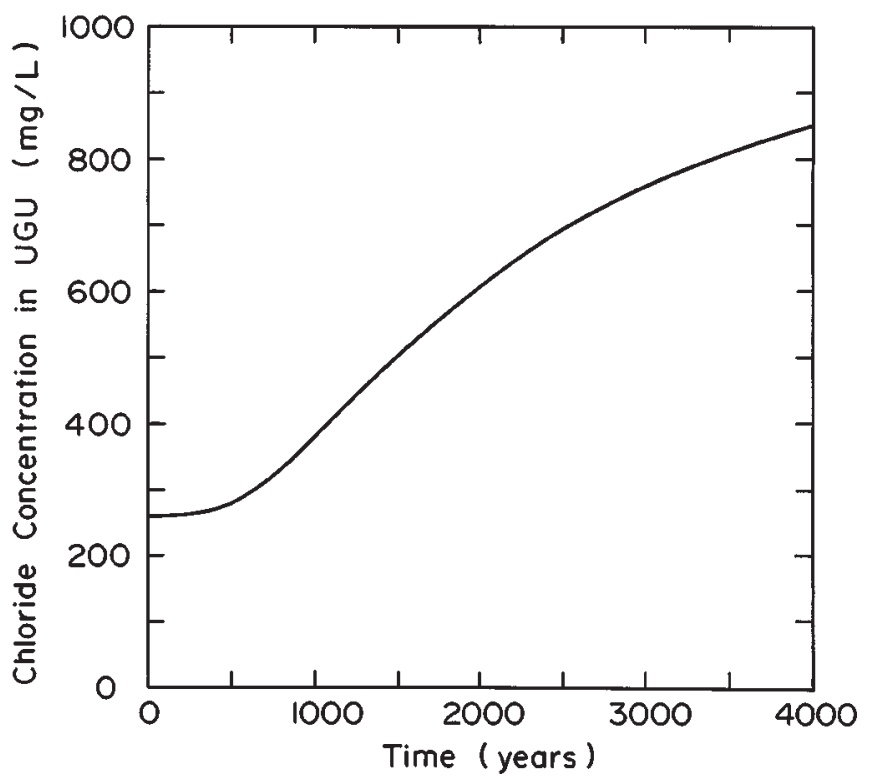

(1) Prior to construction of the SLCL for any given cell, the excavated base of the landfill is inspected by a qualified geotechnical engineer. Any soil that may be susceptible to piping under upward gradients (e.g., silt lenses) is removed and replaced by appropriately engineered compacted clay (to be covered by a suitable geotextile) prior to placement of the SLCL.

(2) The SLCL is designed with $150 \mathrm{~mm}$ diameter perforated high density polyethylene (HDPE) pipes along the east and west edges (see Fig. 3) and was constructed by placing the pipes and $300 \mathrm{~mm}$ of coarse gravel (39 $\mathrm{mm}$ nominal size crushed dolomite limestone with not less than $40 \%$ magnesium carbonate specified) on the prepared base. The coarse gravel is specified to have negligible fines (less than $5 \%$ finer than $19 \mathrm{~mm}$ ) so as to avoid any reduction in void space, and hence hydraulic conductivity, of the SLCL. It was found to be important to monitor this during construction of cells 1 and 2 .

(3) During construction, the elevations of the contact between the SLCL and overlying compacted liner are carefully controlled so as to avoid irregularities that would allow significant zones where pockets of air could be caught during saturation of the SLCL.

(4) Air vents are provided at high points so as to allow escape of air during saturation of the SLCL. These air vents are isolated from the waste and are designed and constructed such that they will not provide a potential conduit for leachate migration from the waste to the SLCL.

\section{Saturation and operation of the SLCL}

Some rainwater accumulates in the SLCL during construction and subsequently there is groundwater flow into the SLCL. Both mechanisms serve to fill portions of the pore space with water; however, because of the low hydraulic conductivity of the till and the correspondingly small flow into the SLCL it would take far too long for the layer to be initially saturated without human intervention. Thus, although the barrier system for cell 1 (west) was constructed in 1992-1993 and cell 1 (east) was completed in 1995, prior to April 1998 the SLCL remained unsaturated. Up to this time there had been a hydraulic trap between the UGU and the SLCL (except for short periods during depressurization pumping) but downward gradients from the primary leachate collection system (PLCS) to the SLCL. Monitoring of the water quality in the SLCL indicated that leachate parameters were not elevated (Gartner Lee Ltd. 1999), and so advantage was taken of the depressurization of the UGU necessary to allow construction of cell 2 to use water pumped from the UGU to saturate the SLCL and fill it to a point where a hydraulic trap would develop between the UGU and the PLCS in cell 1 once the water levels in the UGU recovered from depressurization. The SLCL for each cell is saturated by introducing water pumped into the manholes at the west end of the cell. The water levels are to be increased sufficiently slowly to allow the expulsion of air. To avoid potential blowout after construction of a cell, the head in the SLCL is not allowed to exceed a specified value until the primary leachate collection system gravel at any point in the cell is covered by $2 \mathrm{~m}$ (or more) of waste. This procedure, which was adopted for cell 1, is likely to be adopted for pressurizing the SLCL for the other cells after they are constructed.

After the water levels in the SLCL have been brought to a level above the clay liner at all points in the cell and below the potentiometric surface in the UGU, there is a hydraulic trap between the UGU and the leachate collection system. Under design conditions, the water levels in the SLCL are to be monitored on a regular basis (monthly) and this is expected to continue for the contaminating lifespan of the landfill. Some change in the water level in the SLCL is expected to occur with time. The equilibrium water level will depend on the long-term average head in the UGU, the hydraulic conductivity of the till and liner, and any leachate mounding in the landfill.

\section{Excessive leachate mounding}

At some time in the future, clogging of the primary leachate collection system may result in an increase in leachate head in the landfill and hence a loss of the hydraulic trap between the landfill and the SLCL. If the average leachate head acting on the liner in a landfill cell exceeds the head in the SLCL, below that cell, the SLCL is to be activated by pumping water from the manholes in the SLCL so as to maintain the head in the SLCL at a specified level.

\section{Lowering of water levels in the UGU}

If the annual average water level in the UGU drops below the level required to maintain the natural hydraulic trap, water may be added to the SLCL. In this way, a specified head can be maintained in the SLCL such that there is a hydraulic trap between the SLCL and the PLCS.

\section{Diffusion tests and diffusion against advection}

Since the Halton Landfill is designed as a hydraulic trap, under these conditions the primary mechanism for potential 
Fig. 8. Laboratory test demonstrating hydraulic containment. $c_{0}$, initial source concentration; $t$, time; $v_{\mathrm{a}}$, Darcy velocity.

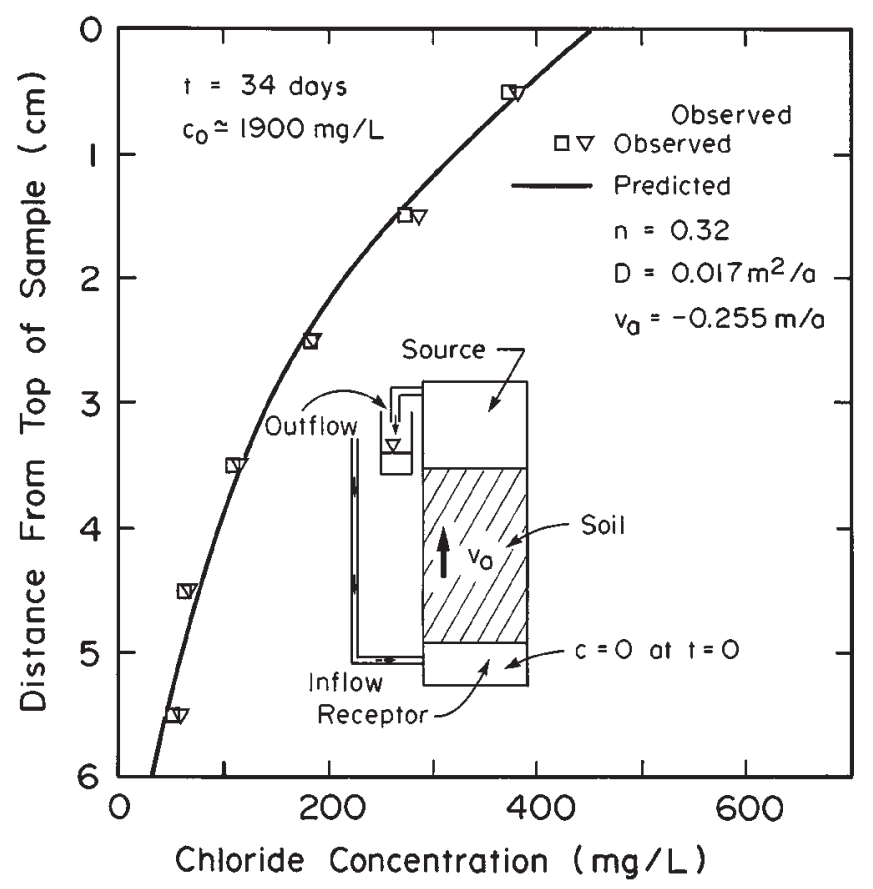

contaminant migration to the underlying aquifer is molecular diffusion. A number of tests were performed to establish the diffusion coefficient for the two critical contaminants (chloride and dichloromethane). The first series of tests involved the diffusion of chloride through both compacted upper till (i.e., liner material) and intact lower till (the primary natural aquitard). These tests, which were performed at $10^{\circ} \mathrm{C}$ using a sample of leachate from the Burlington Landfill, yielded an effective diffusion coefficient of between 0.016 and $0.022 \mathrm{~m}^{2} / \mathrm{a}$ and an effective porosity of between 29.5 and $35.2 \%$ for compacted till and a diffusion coefficient of $0.016 \mathrm{~m}^{2} / \mathrm{a}$ and effective porosity of $20 \%$ for the intact lower till.

A second series of tests was performed to examine the suitability of the proposed modelling technique (Rowe and Booker 1990) for modelling (i) diffusion against an inward advective flow, and ( $i$ i) the case where an air pocket formed between the fluid in the SLCL and the compacted clay liner. The tests involved taking a $6 \mathrm{~cm}$ long sample of compacted liner material and inserting it into a test cell as shown in the insert to Fig. 8, taking care to ensure a good seal between the sample and the cell. A vertical stress of $200 \mathrm{kPa}$ was then applied to simulate a field vertical stress and to prevent "blow out" of the sample when the lower reservoir was pressurized. The sample was allowed to consolidate and the upper reservoir was then filled to a depth of about $4.5 \mathrm{~cm}$ with a sodium chloride solution having a chloride concentration of 1900-2000 mg/L (depending on the test). The lower reservoir (simulating the fluid in the SLCL) was pressurized to (i) 1 , (ii) 30 , or (iii) $43 \mathrm{kPa}$ to simulate (i) pure diffusion and upward Darcy velocities of (ii) 0.17 and (iii) $0.25 \mathrm{~m} / \mathrm{a}$.

As water flowed upward through the sample, the excess fluid in the upper (source) reservoir was collected (with the head in the source reservoir being maintained constant). The concentrations in the upper and lower reservoirs were monitored with time. At the end of the tests the sample was
Fig. 9. Laboratory test showing diffusion of chloride to a pressurized air pocket.

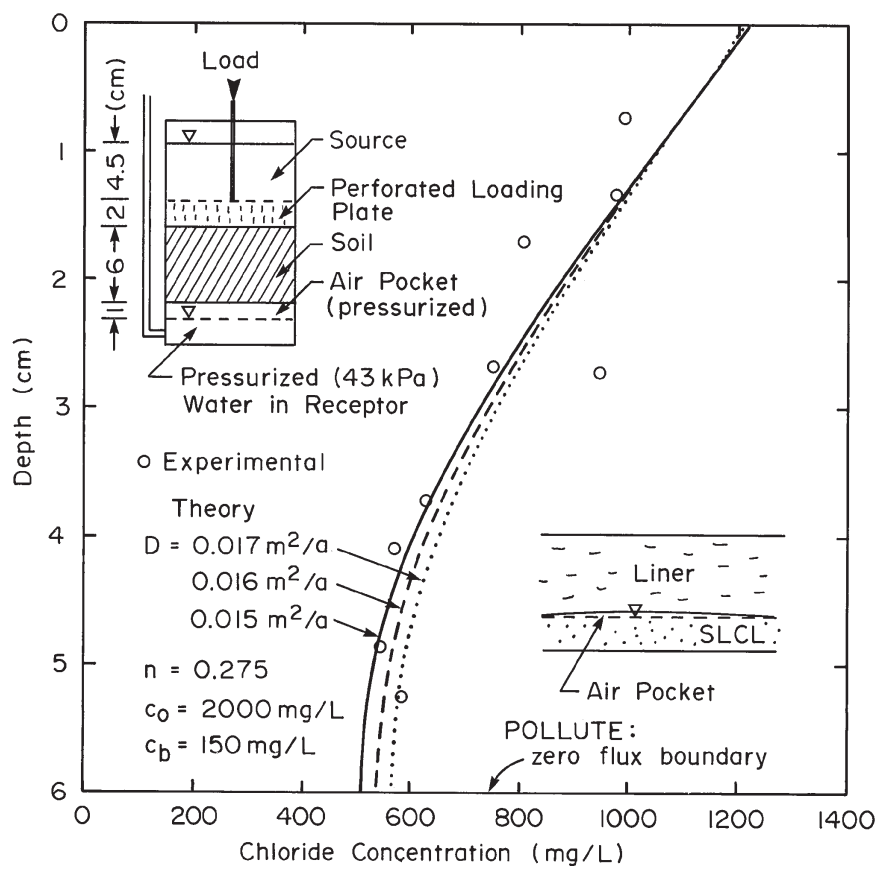

sliced, about $3 \mathrm{~mL}$ of pore water was squeezed out of each slice, and the pore water was analyzed. The concentration profile with depth through the sample was established as shown in Fig. 8 for the test conducted at the highest Darcy velocity examined $\left(v_{\mathrm{a}}=0.25 \mathrm{~m} / \mathrm{a}\right)$.

The diffusion coefficient of $0.017 \mathrm{~m}^{2} / \mathrm{a}$ deduced from the pure diffusion test using an $\mathrm{NaCl}$ solution as source and the measured Darcy velocity were then used in the POLLUTE program (Rowe and Booker 1990) to calculate the concentration profile through the sample at the end of the tests, and this is compared with the observed concentration profile in Fig. 8, which shows that the theoretical analysis based on a diffusion coefficient from a different test gives a good prediction of diffusion against a strong upward advective velocity. Also, these tests clearly demonstrate that there can be diffusion against even a strong inward flow (much larger than anticipated for field conditions as discussed in a later section).

The design, construction, and operation of the SLCL are intended to minimize the formation of air pockets between the SLCL and the overlying compacted clayey liner (see Fig. 2). However, it must be recognized that unless the grades on the bottom of the liner are perfect, there are likely to be occasional small air pockets caught between the SLCL and the liner (see insert to Fig. 9). The pressurizing of the SLCL to generally induce upward flow through the liner (initially by man but then maintained by the hydraulics of the system with water flowing upward from the UGU) can be expected to cause a shrinkage of these compressible air pockets (due to the applied confining fluid pressure) and to cause some air to dissolve. Even so, a few localized air pockets are expected to exist. This raises the question as to what effect these air pockets will have on contaminant transport. 
Table 3. Assumed leachate characteristics for critical contaminants (see Rowe 1994 for details).

\begin{tabular}{|c|c|c|c|c|}
\hline Parameter & $\begin{array}{l}\text { Initial source } \\
\text { concentration } c_{\mathrm{o}}\end{array}$ & Mass ratio $p$ & $\begin{array}{l}\text { Octanol-carbon partitioning } \\
\text { coefficient } K_{\mathrm{oc}}(\mathrm{mL} / \mathrm{g})\end{array}$ & $\begin{array}{l}\text { Half-life } \\
t_{1 / 2} \text { (years) }\end{array}$ \\
\hline Chloride & $1600-2500 \mathrm{mg} / \mathrm{L}$ & $1.8 \mathrm{~g} / \mathrm{kg}$ & - & - \\
\hline Benzene & $20 \mu \mathrm{g} / \mathrm{L}$ & $0.014 \mathrm{mg} / \mathrm{kg}$ & 862 & 25 \\
\hline Dichloromethane & $3300 \mu \mathrm{g} / \mathrm{L}$ & $2.3 \mathrm{mg} / \mathrm{kg}$ & 345 & 10 \\
\hline Vinyl chloride & $55 \mu \mathrm{g} / \mathrm{L}$ & $0.039 \mathrm{mg} / \mathrm{kg}$ & 375 & 25 \\
\hline
\end{tabular}

Based on fundamental considerations, one would expect that the presence of a sufficiently large pressurized air pocket would prevent any advective flow directly above the air pocket and hence there would be pure diffusion across the liner between the leachate collection system and the air pocket. This leaves the question of what happens when the contaminant reaches the air pocket. In the case of ionic species such as chloride which have an extremely low diffusion coefficient in air, one may hypothesize that the air pocket will act as a zero-flux boundary (allowing negligible migration across the air pocket, since there is no flow and negligible diffusion in air). Thus, since the most critical contaminant for the Halton Landfill is chloride, it should be conservative to neglect the effect of air pockets with respect to chloride migration if the above hypothesis is valid.

To check the hypothesis outlined above, two identical experiments were performed where the compacted sample was prepared and the load applied and consolidation allowed as described earlier. However, before pressurizing the lower reservoir, a $1 \mathrm{~cm}$ air pocket was created at the bottom of the compacted clay (i.e., between the clay and the underlying water as shown in the insert to Fig. 9). The water in the lower reservoir was then pressurized to $43 \mathrm{kPa}$ (as previously) and the sodium chloride solution was added to the upper (source) reservoir.

As expected, there was no measurable flow through the sample (despite a difference of about $43 \mathrm{kPa}$ in pressure between the top and bottom of the sample) and, as shown in Fig. 9, the concentration profile through the sample was well predicted by POLLUTE (Rowe and Booker 1990) using the diffusion coefficient from an independent pure diffusion test, assuming no advection and a zero-flux boundary at the base of the compacted clay. As hypothesized, no increase in chloride concentration was observed in the receptor water despite the significant increase that occurred at the bottom of the compacted sample. This provided additional support for the action of the air pocket as a zero-flux boundary under hydraulic trap pressurization. This also suggests that it is conservative to neglect the effect of air pockets when assessing the contaminant migration of chloride through the liner and into the SLCL.

\section{Contaminant impact calculations and contaminating lifespan}

A detailed description of the contaminant transport modelling is beyond the scope of this paper; however, it is useful to summarize the cases considered and the findings, since this has direct relevance to the contaminating lifespan of the landfill and the required service life of the engineered systems (see Rowe 1995 for full details). Based on the hydrogeologic data and design details, contaminant impact calculations were performed along the same flow line $\mathrm{A}-\mathrm{A}^{\prime}$ used for flow modelling (Fig. 5) using a finite layer model (Rowe and Booker 1985, 1990) to assess the potential impact of the landfill on groundwater quality in the upper granular unit. The assumed leachate characteristics were taken to be those values given in Table 3 and are based on the Interim Waste Authority Study (Rowe 1994), which also formed the basis for current Ontario Ministry of Environment (MOE 1998) default values. Three scenarios were examined.

\section{Long-term operation under design conditions}

The potential impact under design conditions with a leachate mound controlled to $0.3 \mathrm{~m}$ (or less) above the elevation of the nominal top of the compacted clay liner and passive operation of the SLCL (i.e., no human addition or removal of water from the SLCL) was modelled assuming that the water levels in the upper granular unit are within the expected range. Based on the calculations performed for these conditions, the chloride concentration in the UGU may increase by $15-35 \mathrm{mg} / \mathrm{L}$ (i.e., an amount similar to typical variability of chloride concentration in the UGU previously noted) after 530-650 years; however, even this very small increase could be reduced to essentially zero if the SLC was operated in an active mode at some future time. Negligible increase $(<0.1 \mu \mathrm{g} / \mathrm{L})$ in the concentration of organics was predicted.

\section{Excessive leachate mounding}

The potential impact if there is leachate mounding on the liner which exceeds the design condition and would cause a loss of the hydraulic trap was modelled for two subcases. One assumed that the SLCL is activated and used to control potential impact as discussed earlier. Calculations indicate that even with a complete failure of the PLCS, the operation of the SLCL in this manner should control chloride impacts on the UGU to less than $50 \mathrm{mg} / \mathrm{L}$ and the impact of organic compounds to negligible levels.

The second case assumed that the operation of both the PLCS and SLCL was terminated and this case was used to obtain an estimate of the contaminating lifespan of the facility. For example, Fig. 10 shows the calculated increase in chloride content in the UGU for termination of the engineered system at 200, 400, and 600 years. Due to the high and variable chloride concentration in the UGU, there are insufficient data to allow a precise evaluation of the contaminating lifespan and hence the time at which the operation of the PLCS (and SLCL if activated) could be terminated. Based on available information, the contaminating lifespan is likely to exceed 100 years and the calculations indicate that it could range between 100 and 600 years (depending on assumptions and the level of chloride increase considered to 
be acceptable). An improved estimate of contaminating lifespan will be obtained after closure of several cells and when a trend of decreasing chloride concentration with time is detected in the leachate using the technique described by Rowe et al. (1995).

The critical contaminant controlling the contaminating lifespan is chloride. With respect to potential impact on the UGU, the contaminating lifespan for organics is calculated to be about 20 years after the peak concentration is reached in the landfill.

\section{Lowering of water levels in upper granular unit}

This case examined the addition of water to the SLCL to control impact in the event that the water levels in the UGU drop below the level of the design leachate mound as discussed earlier. Calculations indicated that the chloride impact could be controlled to less than $50 \mathrm{mg} / \mathrm{L}$ and there would be negligible impact due to organic compounds.

\section{Recompacted clayey silt till liner}

Since the hydraulic conductivity of the unweathered upper till potentially exceeded $1.4 \times 10^{-7} \mathrm{~cm} / \mathrm{s}$, the conditions of approval required that $1 \mathrm{~m}$ (or more) of unweathered upper till be remoulded to achieve the lowest practical hydraulic conductivity. As discussed, the design cross section (see Fig. 2) involves a $1.2 \mathrm{~m}$ thick compacted clayey till liner which is shaped to give a maximum liner thickness of $1.5 \mathrm{~m}$ at high points. The specifications for the liner, at the geotextile separator layers above and below the liner, were developed based on a detailed trial liner investigation (see Rowe et al. 1993) which demonstrated the feasibility of constructing a $1.2 \mathrm{~m}$ thick recompacted liner (using unweathered upper till) over a stone layer (the simulated SLCL) and achieving a hydraulic conductivity of less than $3 \times 10^{-8} \mathrm{~cm} / \mathrm{s}$ over more than $1 \mathrm{~m}$ of this thickness.

The on-site Halton Till used as liner material ranged from a partly weathered brown grey to unweathered grey soil with a clay content typically between 21 and $38 \%$ and plasticity index between 9 and $15 \%$. The clay minerals consisted mostly of illite $(35-37 \%)$, chlorite $(8 \%)$ in the unweathered till and vermiculite-smectite $(8 \%)$ in the weathered till. The cation exchange capacity ranged between 14 and 18 mequiv./100 g (R.M. Quigley, personal communication). Based on the preliminary studies (Rowe et al. 1993), the liner material was specified to have a minimum clay content of $20 \%$, plasticity index of $7 \%$, and a grain-size distribution with greater than $80 \%$ finer than $2 \mathrm{~mm}$ (i.e., passing No. 10 U.S. sieve). The specifications called for removal of all cobbles, stones, and clods greater than $100 \mathrm{~mm}$ in size. Due to the variability of the till, standard Proctor compaction tests indicated that the optimum water content varied between 10.5 and $12.4 \%$ and the maximum dry density varied between 1930 and $2025 \mathrm{~kg} / \mathrm{m}^{3}$. The compaction water content was specified to be between 2 and $4 \%$ above standard Proctor optimum, subject to the additional restriction that it should not be less than $12 \%$ or more than $16 \%$. The compacted dry density was specified to exceed $95 \%$ of standard Proctor optimum. Compaction was specified using either a CAT815B or CAT825B tamping foot compactor (minimum mass of $15000 \mathrm{~kg}$ with feet exceeding $150 \mathrm{~mm}$ in length
Fig. 10. Calculated increase in chloride concentration with time in the UGU, assuming that the operation of both the PLCS and the SLCL is terminated at time $T_{\mathrm{f}}(200,400$, and 600 a). $p$, mass ratio.

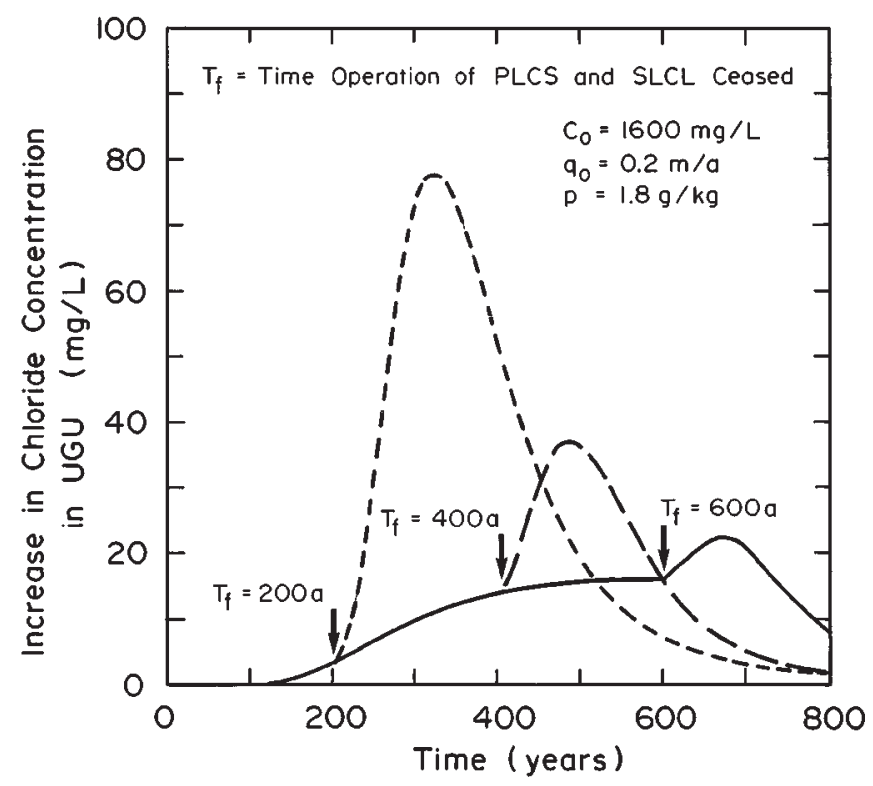

and not exceeding $230 \mathrm{~mm}$ ) except for the first lift (i.e., the lift directly over the SLCL; see Fig. 2), which was a sacrificial lift compacted with a smooth drum finishing roller. From the perspective of a contractor, acceptance of any lift of the liner was based on the requirement that $(i)$ the average water content lie between 1 and $4 \%$ wet of standard Proctor optimum water content, $w_{\text {opt }}$; (ii) no water content less than $w_{\text {opt }}$; (iii) $90 \%$ of all water contents, $w$, within the range $12 \leq w \leq 16 \%$; (iv) average dry density exceeds $95 \%$ of standard Proctor maximum dry density $\left(\rho_{\max }\right)$; and $(v)$ minimum dry density exceeding $90 \%$ of $\rho_{\max }$.

Recognizing the variability of the material, compaction tests were also performed at several levels of compaction energy (typical results are plotted in Fig. 11) and the line of optimums was established as shown in Fig. 11. The line of optimums corresponds to a degree of saturation of $86 \%$. Also plotted in Fig. 11 is the zero air voids line. To obtain an adequate liner it was expected that the water content and density data for the compacted liner should typically plot above the line of optimums. The hydraulic conductivity (based on flexible-wall permeameter tests) was to be less than $3 \times 10^{-8} \mathrm{~cm} / \mathrm{s}$.

Monitoring of the construction of the liner for cells 1 and 2 yielded quality-control data as summarized in Table 4. The average field water content over the period of construction (1992-1995) consistently fell within the specified range (see Table 4), although typically 13-29\% (average of $18 \%$ ) of water-content samples fell outside the specified range. Based on all the data, the mean and standard deviations of water content were 14.5 and $1.1 \%$, respectively, for cell 1. For cell 2 (west), constructed in 1998, the average water content again consistently fell within the specified ranges, with between 1 and $11 \%$ of the data points falling outside the specified range. The mean and standard devia- 
Fig. 11. Dry density - water content relationship for Halton Till liner material and field compaction data.

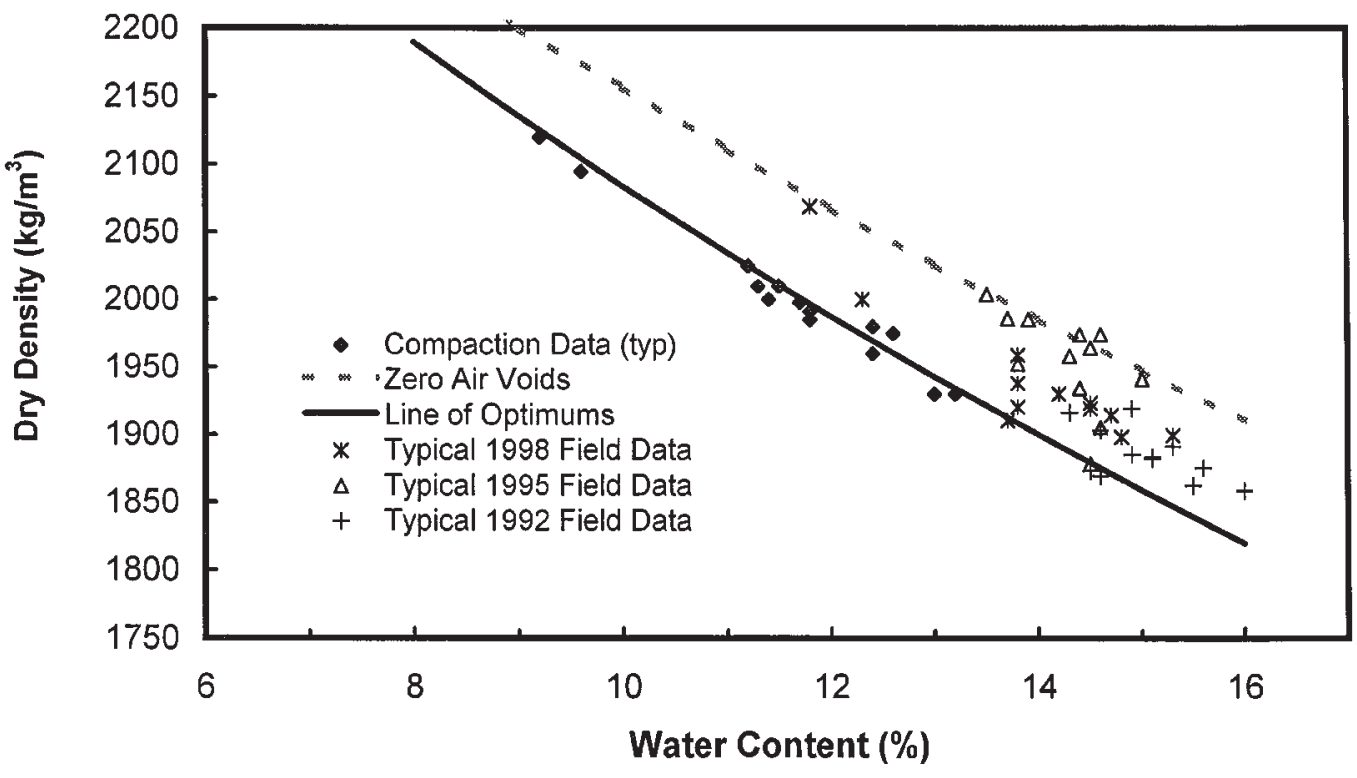

Table 4. Data relating to construction of the liners for cell 1 in 1992-1995 and cell 2 in 1998.

\begin{tabular}{|c|c|c|c|c|c|c|c|}
\hline & \multicolumn{3}{|c|}{ Water content $(\%)$} & \multirow{2}{*}{$\begin{array}{l}\text { Outside specified } \\
\text { range* }(\%)\end{array}$} & \multirow{2}{*}{$\begin{array}{l}\text { Avg. clay } \\
\text { content }(\%)\end{array}$} & \multirow{2}{*}{$\begin{array}{l}\text { Avg. plastic } \\
\text { limit }(\%)\end{array}$} & \multirow{2}{*}{$\begin{array}{l}\text { Avg. plasticity } \\
\text { index }(\%)\end{array}$} \\
\hline & Mean & $\mathrm{sd}$ & No. of values & & & & \\
\hline \multicolumn{8}{|l|}{ Cell 1: 1992} \\
\hline Report 5 & 14.3 & 1.42 & 108 & 31 & 24.9 & 15.8 & 13.9 \\
\hline Report 6 & 14.4 & 1.33 & 56 & 23 & 24.7 & 13.8 & 13.2 \\
\hline Report 8 & 14.4 & 1.52 & 82 & 33 & 23.6 & 16.0 & 12.4 \\
\hline Report 18 & 15.0 & 1.09 & 104 & 16 & 24.9 & 15.4 & 13.4 \\
\hline Report 19 & 15.3 & 1.04 & 29 & 14 & 30.8 & 15.5 & 12.8 \\
\hline Report 20 & 15.0 & 1.21 & 58 & 23 & - & - & - \\
\hline Report 21 & 15.2 & 1.30 & 41 & 24 & - & - & - \\
\hline \multicolumn{8}{|l|}{ Cell 1: 1995} \\
\hline \multicolumn{8}{|l|}{ Cell 2: 1998} \\
\hline Report 7 & 14.6 & 0.7 & 4.1 & 2 & 36.6 & 14.3 & 14.7 \\
\hline Report 9 & 14.5 & 0.8 & 103 & 1 & 37.5 & 15.8 & 13.8 \\
\hline Report 11 & 14.0 & 0.8 & 23 & 4 & 32.1 & 15.3 & 10.0 \\
\hline Report 16 & 13.8 & 0.9 & 45 & 11 & & & \\
\hline Report 17 & 14.1 & 0.7 & 103 & 0 & & & \\
\hline Report 22/23 & 13.8 & 0.9 & 108 & 4 & 24.7 & 14.9 & 9.3 \\
\hline
\end{tabular}

Note: All reports were prepared by Peto MacCallum Ltd. for Proctor and Redfern Ltd.; analysis of data prepared by authors of this paper. *Specified range: optimum $[(12.3-12.4 \%)]+1 \%$ to $16 \%$.

tion of the water content for cell 2 (west) were 14.1 and $0.8 \%$, respectively.

Typical liner data from the 1992, 1995, and 1998 liner constructions are plotted in Fig. 11 (due to the large amount of available data (704 data points) only 12 randomly selected points are plotted for each year for clarity of presentation). The data typically fall on or above the line of optimums, with the degree of saturation ranging between 86 and $100 \%$. It is noted that the same contractor was used for 1992, 1993, and 1998 liner construction; a different contractor won the bid in 1995 .

Given that the site was visually inspected for macrostructures and the field water content and density data corresponded to a degree of saturation of $86 \%$ or greater and generally fell 
on or above the line of optimums, it was considered adequate to assess hydraulic conductivity based on flexible-wall permeameter tests. These tests were conducted at a confining pressure of $100 \mathrm{kPa}$ using Shelby tube samples (for justification see Rowe et al. 1993 and Rowe 2000). A total of 66 tests were conducted for cell 1 (6.5 tests/ha) and the data are summarized in Fig. 12. The maximum measured hydraulic conductivity was $1.6 \times 10^{-8} \mathrm{~cm} / \mathrm{s}$, and hence even the maximum measured value is well below the specified maximum harmonic mean hydraulic conductivity (at $100 \mathrm{kPa}$ ) of $3 \times 10^{-8} \mathrm{~cm} / \mathrm{s}$. The hydraulic conductivity data for the cell 1 liner were approximately log-normally distributed (see Fig. 12), with a geometric mean of $1 \times 10^{-8} \mathrm{~cm} / \mathrm{s}$ and a standard deviation ( $\log _{10}$ unit) of 0.1 . For the cell 2 (west) liner, 26 hydraulic conductivity tests were performed (4.7 tests/ha) and these gave results very similar to those for cell 1 , with a maximum value of $1.4 \times 10^{-8} \mathrm{~cm} / \mathrm{s}$, a geometric mean of $0.98 \times 10^{-8} \mathrm{~cm} / \mathrm{s}$, and a standard deviation $\left(\log _{10} k\right)$ of 0.11 . Thus, the quality of the cell 2 liner appears to be similar to that of cell 1 and the quality of the 15 ha of the liner constructed at the Halton Landfill between 1992 and 1998 appears to be similar to that obtained at the Keele Valley Landfill (King et al. 1993).

A key component of the liner construction protocol was the full-time on-site presence of a soils technician under the direction of a qualified geotechnical engineer who were responsible for ( $i$ ) maintaining the quality of the liner (in terms of evaluating soil suitability and water content); and (ii) ensuring the liner was kept moist, inspecting for any desiccation cracking and requiring that any desiccated areas be removed and replaced. The same on-site soils technician was used in each construction season.

\section{Conclusions}

This paper has summarized key considerations related to the design and construction of the Halton Landfill to operate as a hydraulic trap (i.e., hydraulic containment). A number of specific observations and conclusions can be drawn from this work.

(1) It is essential that there be a detailed hydrogeologic investigation prior to the approval and design of a landfill. In the case of the Halton Landfill, the detailed hydrogeologic investigation conducted in 1990-1991 revealed the following information that was not evident from the initial 1985-1986 investigation: $(i)$ the unweathered upper till was fractured throughout its entire thickness; (ii) the hydraulic conductivity of the unweathered upper till was potentially greater than the value of $1.4 \times 10^{-7} \mathrm{~cm} / \mathrm{s}$ specified by the Joint Board (who approved the site) as the point at which a compacted clay liner was required; (iii) the primary potential receptor aquifer was the upper granular unit (UGU), which was continuous but of variable thickness beneath the landfill; and (iv) there was a high chloride background concentration ( $\cong 260 \mathrm{mg} / \mathrm{L}$ ) in the potential receptor aquifer (the UGU), with the standard deviation of the chloride concentration in individual monitors ranging from 0.5 to $50 \mathrm{mg} / \mathrm{L}$.

(2) Careful consideration should be given to the potential natural variation in water levels in the potential receptor aquifer, especially when the landfill is to be designed to operate as a hydraulic trap. In the Halton case, the water levels
Fig. 12. Hydraulic conductivity data for cell 1 compacted liner.

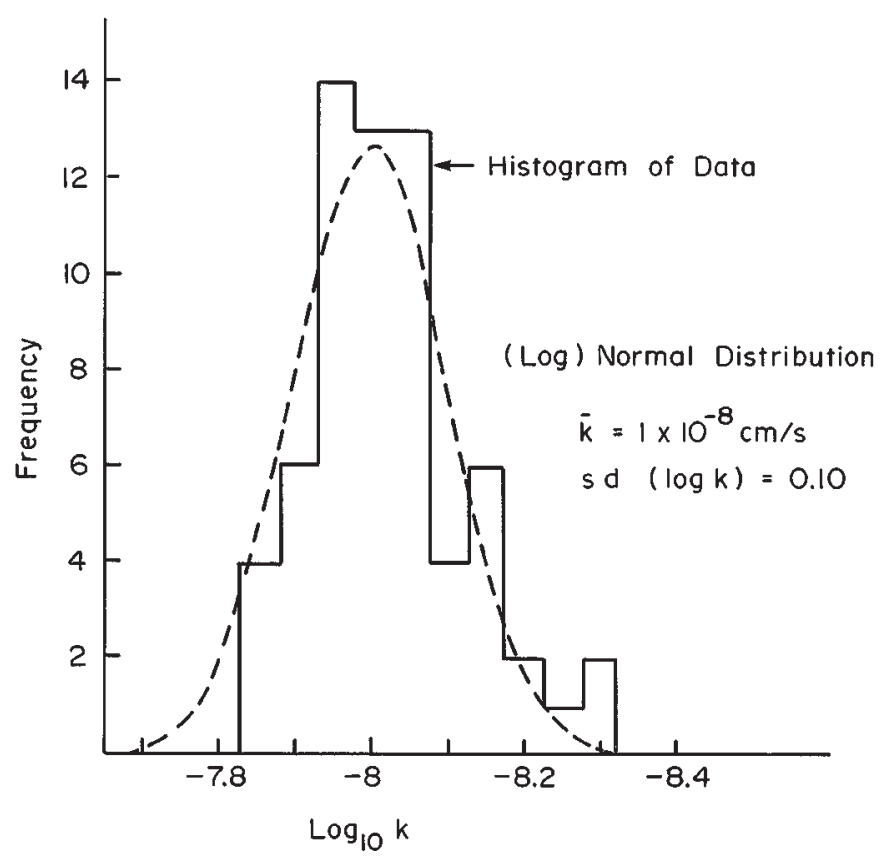

dropped by up to $2.8 \mathrm{~m}$ between the initial hydrogeologic investigation in 1985-1986 and the detailed investigation in 1990-1991. This required significant lowering of the base of the landfill relative to the elevation proposed in 1986.

(3) The final design of the Halton Landfill incorporated a $0.3 \mathrm{~m}$ thick coarse gravel sub-liner contingency layer (SLCL) beneath the compacted clay liner. Under normal operation, this layer will be saturated and the heads in this layer will be controlled by the system. Flow will occur from the receptor aquifer to the SLCL and then through the compacted clay liner to the primary leachate collection system. The expected upward Darcy velocity is small $(0.0005 \mathrm{~m} / \mathrm{a}$ or less). In the event of some failure of the primary leachate collection system (e.g., due to clogging) or an unexpected drop in water level in the receptor aquifer, this layer has been designed so that it can be activated to control contaminant impact on the receptor aquifer.

(4) The results from computer modelling of the potential hydraulic "shadow" cast by the landfill (cutoff of recharge and removal of water from receptor aquifer due to operation of the hydraulic trap) were considered in establishing the base contours of the landfill. These analyses highlighted the need to examine the potential interaction between the engineered facility and the hydrogeology in the landfill design.

(5) Laboratory experiments demonstrated that there can be outward diffusion from a contaminant source even when there is an inward flow (hydraulic trap) through clay material of $0.25 \mathrm{~m}^{3} /\left(\mathrm{a} \cdot \mathrm{m}^{2}\right)$. The theoretical model made a good prediction of the variation in concentration with depth through the sample based on a diffusion coefficient obtained from an independent diffusion test and the measured Darcy velocity.

(6) The potential presence of isolated pressurized air pockets in the subliner contingency layer below the compacted clay liner was recognized. Laboratory tests indicated that this air pocket will act essentially as a zero-flux boundary 
with respect to the migration of chloride from the landfill and through the clay liner. The theoretical approach of Rowe and Booker (1990) provided a good prediction of the experimental concentration profile based on pure diffusion and the air pocket being modelled with a zero-flux boundary. Thus it was conservative to neglect the effect of these air pockets in assessing the potential impact due to chloride.

(7) The operation of the hydraulic trap is predicted to change the vertical gradient at the site and cause upward flow from the aquifer below the primary receptor aquifer (the UGU) to the leachate collection system. Due to the high concentration of chloride in the aquifers below the primary receptor aquifer, there is potential that this change in flow condition could cause increased upward migration of chloride from below the UGU and hence cause an increase in concentration in the aquifer. However, modelling indicated that in this case the flows were sufficiently small that diffusion would control contaminant migration and that over the whole contaminating lifespan of the landfill there would be no measurable impact on the quality of the UGU due to this mechanism.

(8) Contaminant impact calculations indicate that under designed operating conditions the landfill should have minimal impact on the quality of groundwater below the site. Chloride may increase by between 15 and $35 \mathrm{mg} / \mathrm{L}$ (depending on assumptions) 530-650 years from now; however, these changes are within the range of natural variation in background concentrations. Organic contaminants (vinyl chloride, dichloromethane, benzene) were predicted to have negligible impact (well below current normal detection limits).

(9) Modelling indicated that in the event of a failure of the primary leachate collection system (due to clogging), or unexpected lowering of water levels in the UGU, the SLCL could be used to control impacts in the UGU to negligible levels. Under these conditions, an increase in chloride concentration in the UGU is predicted to be less than $50 \mathrm{mg} / \mathrm{L}$ (after several hundred years) and the increase in the concentration of organic contaminant is predicted to be less than current detection levels and orders of magnitude below current drinking water objectives.

(10) A compacted clayey liner with a nominal thickness of $1.2 \mathrm{~m}$ was incorporated into the design. The specified hydraulic conductivity was $3 \times 10^{-8} \mathrm{~cm} / \mathrm{s}$. The data relating to water-content control, maximum dry density, clay content, and plasticity index have been summarized. The mean liner water content was $14.5 \%$ (cell 1) and $14.1 \%$ (cell 2), with a standard deviation of $1.1 \%$ (cell 1) and $0.8 \%$ (cell 2). Hydraulic conductivity tests conducted on 66 samples taken from the liner for cell 1 and 26 samples from the liner for cell 2 indicated that the hydraulic conductivity of the liner stress was about $1 \times 10^{-8} \mathrm{~cm} / \mathrm{s}$. The maximum mean hydraulic conductivity was $1.6 \times 10^{-8} \mathrm{~cm} / \mathrm{s}$. The data appear to be log-normally distributed with standard deviation $\left(\log _{10}\right)$ of 0.1 . The hydraulic conductivity is similar to that observed by King et al. (1993) for the Keele Valley Landfill using a similar Halton Till and similar construction specifications. The liner had a degree of saturation (after compaction) of $86 \%$ or higher, and essentially all compaction data points (water content $\omega$, dry density $\rho_{\mathrm{d}}$ ) fell above the line of optimums.

\section{Acknowledgements}

Many people contributed to the work reported in this paper. Special thanks are extended to Mike Jones, E.J. Wexler, Bob Tate, Bill Priestner, Frank Barone, Gary Lusk, Joe de Konig, Brian Wadell, Kazem Badv, and Stan Feenstra as well as to Peto MacCallum Ltd. who were responsible for supervising the liner construction and routine geotechnical testing.

\section{References}

Burke, L.M., and Haubert, A.E. 1991. Burying by the bale. Civil Engineering, 61(8): 58-60.

Gartner Lee Ltd. 1991. Hydrogeological investigation of the Halton Waste Management Site. Interim report to the Regional Municipality of Halton. Gartner Lee Ltd., Markham, Ont.

Gartner Lee Ltd. 1999. Halton Waste Management Site 1998 monitoring report. Report to the Regional Municipality of Halton, Gartner Lee Ltd., Markham, Ont.

Hydrology Consultants Ltd. 1986. Design and operation report Halton Region Landfill Technical Report, Site D - Milton. Report to the Regional Municipality of Halton, Hydrology Consultants Ltd., Brampton, Ont.

King, K.S., Quigley, R.M., Fernandez, F., Reades, D.W., and Bacopoulos, A. 1993. Hydraulic conductivity and diffusion monitoring of the Keele Valley Landfill liner, Maple, Ontario. Canadian Geotechnical Journal, 30: 124-134.

MOE. 1994. Incorporation of reasonable use concept into groundwater management activities guideline $\&$ procedure B-7. Ontario Ministry of the Environment (MOE), Toronto.

MOE. 1998. Landfill standards - a guideline on the regulatory and approval requirements for new or expanding landfill sites. Ontario Ministry of the Environment (MOE), Toronto. (See also Ontario Regulation 232/98.)

Rowe, R.K. 1994. Leachate characterization. Report to Interim Waste Authority Ltd., Toronto, Ont.

Rowe, R.K. 1995. Contaminant impact and related operational considerations - Halton waste management site. Report to Proctor and Redfern Ltd. Hamilton, Ont.

Rowe, R.K. 2000. Liner systems. In Geotechnical and geoenvironmental engineering handbook. Edited by: R.K. Rowe. Kluwer Academic Publishing, Norwell, Mass. Chapter 25.

Rowe, R.K., and Booker, J.R. 1985. 1-D pollutant migration in soils of finite depth. Journal of Geotechnical Engineering, ASCE, 111: 479-499.

Rowe, R.K., and Booker, J.R. 1990. Program POLLUTE. Geotechnical Research Centre, University of Western Ontario, London, Ont.

Rowe, R.K., Caers, C.J., and Chan, C. 1993. Evaluation of a compacted till liner test pad constructed over a granular subliner contingency layer. Canadian Geotechnical Journal, 30: 667-689.

Rowe, R.K., Quigley, R.M., and Booker, J.R. 1995. Clayey barrier systems for waste disposal facilities. E \& FN Spon (Chapman \& Hall), London. 